\title{
Sujuvaa mutta viron kielen vaikutusta $\quad \boldsymbol{y}$
}

\author{
Yleisten kielitutkintojen arvioijien käsityksiä \\ vironkielisten suomenoppijoiden suullisesta taidosta
}

\author{
SARI AHOLA
}

\section{Johdanto}

Yleisten kielitutkintojen (Ykin) tutkintotodistus on merkityksellinen testiin osallistuville, koska sitä käytetään paitsi niin työelämässä kuin opiskelussa tarvittavan kielitaidon todistamiseen myös Suomen kansalaisuuden edellytyksenä olevan kielitaidon osoittamiseen (Neittaanmäki \& Hirvelä 2014: 50; Soramäki 2014: 40-41). Todistuksen merkityksellisyyden vuoksi on tärkeää, että osallistujien saamat arviot ovat luotettavia ja että arvioijat toimivat testijärjestelmän viitekehyksen ja kielitaitokäsityksen mukaisesti.

Arviointi on kuitenkin inhimillistä toimintaa, jossa arvioijan omat tuntemukset ja käsitykset vaikuttavat taustalla. Luotettava arviointi edellyttääkin sitä, että arvioija tulee tietoiseksi työhönsä vaikuttavista subjektiivista tekijöistä (Tarnanen 2014: 122). Lisäksi arvioijat kiinnittävät usein huomiota sellaisiin kielitaidon piirteisiin, joiden hallintaa he pitävät arvossa (Varis 2012; Honko 2017). Tästä syystä tietyt kielen piirteet voivat saada muita piirteitä merkittävämmän aseman arvioinnissa. Jotta osallistujien saamat arviot olisivat mahdollisimman osuvia, on tärkeää seurata eri tavoin arvioijien toimintaa ja heidän arviointikäyttäytymistään. Jos emme tiedä, mitä he ajattelevat ja tekevät arvioinnin aikana, emme myöskään voi tietää, mitä heidän arvionsa tarkoittavat (Connor-Linton 1995: 763; Johnson \& Lim 2009: 486).

Tässä artikkelissa tarkastelen Ykin suomen kielen arvioijien käsityksiä vironkielisten suomenoppijoiden suullisesta kielitaidosta. Vironkieliset suomenoppijat valitsin tutkimuskohteeksi siksi, että he edustavat Ykin osallistujajoukossa määrältään merkittävää ensikielen ryhmää, mutta myös siksi, että arvioijat pitävät heitä hyvinä suomen kielen taitajina. Arvioijien käsityksiä vironkielisten hyvästä kielitaidosta tukevat lisäksi Ykin tutkintotulokset; noin 97 \% vironkielisistä saavuttaa suomen kielen keskitason tutkinnon kaikista osataidoista (tekstin ja puheen ymmärtäminen, puhuminen ja kirjoittaminen) vähintään taitotason $3\left(\approx \mathrm{B}_{1}\right)$ (ks. Eurooppalainen viitekehys 2003). Tutkimuskysymykseni onkin, mistä piirteistä arvioijien käsitysten mukaan hyvä suullinen kielitaito koostuu ja mitä käsityksiä ylipäätään vironkielisten suomenoppijoiden suulliseen kielitaitoon liittyy. Koska arvioijat myös tunnistavat vironkieliset oppijat hy- 
vin, kuvailen artikkelissa lisäksi sitä, mistä arvioijat heidät tunnistavat ja miten tunnistaminen vaikuttaa kielitaitoa koskeviin käsityksiin.

\section{Arviointi ja vironkieliset oppijat tarkastelun kohteena}

Arviointi liitetään osaksi opettajan ammattitaitoa, minkä vuoksi sen oikeellisuutta ja luotettavuutta ei lähdetä kovin herkästi kyseenlaistamaan, vaikka arvioinnilla on usein merkitystä arvioitavien elämälle. Opetukseen liittyvässä arvioinnissa opettaja voi tukeutua jatkuvaan ja useista suorituksista koostuvaan näyttöön oppijan taidosta, mutta testiarvioinnissa arviointi kohdistuu oppijan senhetkiseen taitoon ja taitoa mitataan tarkasti valikoitujen testitehtävien avulla. Tällainen arviointi edellyttää sitä tekeviltä selkeää näkemystä arvioitavasta taidosta ja arviointikriteereistä mutta myös hyvää päätöksentekokykyä. (Ks. Tarnanen 2002: 48-52.) Artikkelini tavoitteena onkin tuottaa lisätietoa testiarvioinnin parissa toimivien arvioijien arviointikäyttäytymisestä ja arviointiin vaikuttavista tekijöistä.

Vaikka arviointia tehdään yhteiskunnassa joka puolella, Suomessa on varsin vähän Ykin kaltaisia kielitaidon arviointiin keskittyviä testijärjestelmiä. Tästä syystä testiarviointiin liittyvä tutkimus on ollut vähäistä (ks. Huhta 1993; Huhta \& Suontausta 1993; Hildén 2000). Myöskään arvioijien arviointikäyttäytymiseen liittyviä tutkimuksia on Mirja Tarnasen väitöskirjaa (2002) lukuun ottamatta julkaistu vain muutamia (Ahola 2016; Ahola \& Tossavainen 2016). Kotimaiset käsitystutkimukset puolestaan ovat pääosin keskittyneet vieraan ja toisen kielen oppimisen kontekstiin (esim. Nikula 2010; Ilola 2018) tai opettajien käsityksiin kielitaidosta (esim. Jaakkola 1997; Salo 2010), eivät arviointia tekevien opettajien arviointikäyttäytymiseen.

Useat vironkielisiin suomenoppijoihin liittyvät tutkimukset ovat tarkastelleet lähdekielen vaikutusta kohdekieleen (esim. Kaivapalu 2005, 2009; Nissilä 2011; Siivelt \& Mustonen 2013), koska kielten välisten erojen ja samankaltaisuuksien tunnistamisen on todettu edesauttavan kielenoppimista. Oppimista edistää oppijan tietoisuus siitä, milloin lähdekielen malli johtaa kohdekieliseen tuotokseen ja milloin se taas tuo ei-kohdekielen omaisia piirteitä mukanaan (Kaivapalu 2005: 27; 2009: 397). Oppimisessa on siis kyse oppijan omista käsityksistä ja kokemuksista sekä niiden havainnoinnista. Tässä artikkelissa ei kuitenkaan suoranaisesti tarkastella lähdekielen piirteiden vaikutuksia kohdekieleen, vaan painopiste on siinä, miten lähdekielen tunnistettavat piirteet vaikuttavat käsityksiin oppijan kohdekielen taidosta.

Testiarvioinnin parissa toimivat arvioijat usein tunnistavat puhujan ensikielen suullista tuotosta arvioidessaan, mutta tunnistamisen vaikutusta arviointeihin ei ole aikaisemmin Suomessa tutkittu. Sen sijaan englannin kielen arviointiin liittyvissä tutkimuksissa on todettu puheäänellä ja äänensävyllä sekä käsialalla olevan merkitystä kielitaidosta tehtävään arvioon (Orr 2002; Hammerschmidt \& Sudsawad 2004: 188-189; Sato 2011). Lisäksi on havaittu, että ääntämisen (aksentin) perusteella tehdään päätelmiä jopa oppijoiden sosiaalisesta taustasta ja heidän henkilökohtaisista ominaisuuksistaan, kuten ystävällisyydestä ja miellyttävyydestä (Brennan \& Brennan 1981; Nesdale \& Rooney 1996; Lindemann 2005). Myös oppijan aksentin tuttuus (Rubin 
1992; Carey, Mannell \& Dunn 2010) vaikuttaa positiivisesti hänen saamiinsa arvioihin. Aikaisempien tutkimuksien perusteella voidaan siis olettaa, että oppijan ensikieleen liittyvät positiiviset ja negatiiviset käsitykset ja arvioijan kokemukset kyseisen ensikielen oppijoista vaikuttavat arviointiin.

\section{Aineisto ja menetelmät}

Artikkelissa käyttämäni aineisto liittyy Rikkinäistä suomea: Aksenttien arviointi yhteiskunnallisena portinvartijana -tutkimushankkeeseen (2018-2022)1, jossa tarkastellaan viiden ensikielen (arabia, thai, venäjä, suomenruotsi ja viro) kautta vieraan aksentin vaikutusta suullisesta suomen kielen taidosta annettaviin arvioihin. Kutakin ensikieltä aineistossa edustaa kymmenen Ykin suomen kielen keskitason (tasot 3 ja 4) tutkintoon osallistunutta, joiden puhesuoritukset 44 arvioijaa arvioi Ykin taitotasoasteikolle 1-6. Ykin kuusiportainen taitotasoasteikko vastaa Eurooppalaisen viitekehyksen (EVK) taitotasoasteikkoa A1-C2 (Eurooppalainen viitekehys 2003). Keskitason puhumisen osakokeessa on neljä tehtävää, joista yksi valittiin tutkimukseen. Tässä tehtävässä osallistujat puhuivat $1^{1} \frac{2}{2}$ minuutin ajan ohjattujen kysymysten avulla asumiseen liittyvästä aiheesta.

Hankkeen tutkimusaineisto kerättiin internetpohjaisella arviointialustalla ja arvioinnissa käytettiin Ykin puhumisen arviointikriteereitä (ks. Yki). Arviointikriteereissä puhumisen taito on kuvattu yleistaitoa kuvaavan kriteerin lisäksi kuudella analyyttisella kriteerillä: sujuvuus, joustavuus, ilmaisun tarkkuus/laajuus/idiomaattisuus, rakenteiden tarkkuus, ääntäminen ja fonologinen hallinta sekä koherenssi/sidosteisuus. Puhumisen suoritusta arvioidessaan arvioijat hyödyntävät analyyttisia kriteereitä, mutta antavat suorituksesta vain yhden holistisen arvioin. Annettu arvio pohjautuu yleensä niihin kielen piirteisiin, jotka arvioijista parhaiten kuvaavat arvioitavan taitoa (Lumley 2005). Tutkimushankkeessa arvioijia pyydettiin holistisen yleiskriteerin ohessa antamaan arviot myös eri analyyttisista kriteereistä. Lisäksi arvioijilla oli mahdollisuus kirjoittaa perusteluja ja huomioita oppijoiden suorituksista ja antamistaan taitotasoarvioista.

Hankkeessa tutkimuksen keskiössä ovat osallistujan ensikielen tunnistaminen ja sen vaikutus puhumisen arviointiin. Tästä syystä arviointialustalla arvioijia pyydettiin nimeämään oppijan ensikieli. Lisäksi heidän tuli määritellä Likert-asteikon avulla, kuinka varmoja he olivat ensikielen tunnistamisesta sekä kirjoittaa perustelu sille, miten he päätyivät juuri tähän ensikieleen. Ensikielen tunnistaminen on myös tämän artikkelin kannalta keskeinen muuttuja, koska sen avulla voi tarkastella vironkielisiin suomenoppijoihin liittyviä käsityksiä ja sitä, miten tunnistaminen vaikuttaa kielitaitoa koskeviin käsityksiin.

Artikkelini tukena ovat tutkimushankkeen kautta saadut tilastolliset tiedot siitä, kuinka hyvin arvioijat ovat tunnistaneet oppijoiden ensikielen. Pääosassa on kuitenkin laadullinen aineisto, joka pohjautuu arvioijien kirjallisiin huomioihin suorituksista. Ennen laadullista analyysia lähestyin aineistoa tematisoinnin kautta etsimällä arvioi-

1. Suomen Akatemian hanke 315581. 
jien kirjallisissa huomioissa usein esiintyviä aiheita ja tutkimuskysymyksieni kannalta keskeisiä kuvauksia vironkielisten suullisesta taidosta. (Esim. Eskola \& Suoranta 1998: 175-179.)

Analysoin tematisoituja aineistokokoelmia syvemmin diskurssianalyysin avulla edeten tekstuaaliselta ja lingvistiseltä tasolta tulkinnan kautta analyysiin. Diskurssianalyysi sopii tutkimukseeni hyvin, koska arvioijien käyttämät sanat ja ilmaisut kantavat erilaisia merkityksiä ympäröivästä yhteiskunnasta, kulttuurista ja aikakaudesta sekä arvioijia ympäröivistä konteksteista (esim. Pietikäinen \& Mäntynen 2009: 11-14). Analyysissa nämä kirjalliset kommentit asetetaan tilanteiseen, intertekstuaaliseen ja yhteiskunnalliseen kontekstiinsa, jotta ilmaisujen kantamat merkitykset voidaan tulkita. Tässä artikkelissa teen tulkitsevaa analyysia, jossa käyn keskustelua aineiston kanssa ja sitä kautta kuvaan ja selitän arvioinnin taustalla vaikuttavia käsityksiä. (Ks. Siltaoja \& Vehkaperä 2011: 213-218.)

Näkökulmani kielitaitokäsityksiin nojautuu kontekstuaaliseen käsitystutkimukseen (Barcelos 2003: 19-25), jossa käsitykset nähdään tilanteisina ja vuorovaikutuksessa muotoutuvina ja jonka mukaan käsityksiin vaikuttavat toiset ihmiset, yhteiskunta, ympäröivä kulttuuri, tunteet ja yksilön oma minäkuva (Peng 2011: 321; Barcelos \& Kalaja 2011: 285). Vaikka käsitykset nähdäänkin muuttuvina, monitahoisina ja dynaamisina ja joskus jopa ristiriitaisina (Negueruela-Azarola 2011: 360-361), osa niistä muodostaa pysyvämmän käsitysverkoston, jonka muuttaminen ja muokkaantuminen vaatii aikaa (Pajares 1992: 317-318; Woods 2003: 217-218, 226-227). Näkemykseni kielitaitokäsityksistä linkittyy ennen kaikkea sosiokulttuuriseen oppimiskäsitykseen (Vygotsky 1978; Lantolf \& Appell 1994), jossa käsityksiä pidetään sosiaalisesti ja kulttuurillisesti välittyneinä (Negueruela-Azarola 2011: 361). Joskus käsitykset voivat olla jopa ideologisesti värittyneitä, jolloin ne liittyvät kiinteästi kieli-ideologioihin (De Costa 2011: 352).

\section{Arvioijana toimiminen}

Yleisten kielitutkintojen arvioijat ovat kielten opettajia, joiden käsityksiin vaikuttavat opettajan substanssi- ja pedagogisen tiedon muodostama teoreettinen tieto ja sekä käytännön että kokemuksen kautta saatu tieto (Clandinin \& Connelly 1986: 386; Sakui \& Gaies 2003: 154). Käytännöllinen ja kokemuksellinen tieto sisältää myös uskomuksia ja käsityksiä (Golombek 1998: 448), jotka voivat liittyä esimerkiksi kielen luonteeseen, lingvististen piirteiden arvoon ja hierarkiaan (Mercer 2011: 343). Lisäksi arvioijien kielitaitokäsityksiä muokkaavat Ykin arviointikoulutukset ja kokemukset erilaisten testiin osallistujien arvioinnista. Käsityksiä muokkaavat myös muiden arvioijien käsitykset, joista arvioijat tulevat tietoiseksi arviointikoulutuksissa. Arvioijan käsityksiin kielitaidosta, kielitaidon kehittymisestä ja taitotasoista vaikuttavat siis useat tekijät.

Erilaiset käsitykset saattavat näkyä erilaisina arvioina, koska käsitystensä ohjaamina arvioijat voivat tulkita arviointia ohjaavat tehtävät ja arviointikriteerit eri tavoin kuin kollegansa (Orr 2002: 151-153). Arvioijien toimintaan liittyvät tutkimukset (Lim 2011: 550-552; Ang-Av \& Goh 2011: 32; Davis 2016: 132) ovat osoittaneet arvioijien eroavan toisistaan lempeyden ja ankaruuden suhteen, mutta arviointikoulutuksen 
ja -kokemuksen, selkeiden arviointikriteereiden sekä tietoisuuden omasta arviointilinjasta on todettu tukevan arvioijien yhdenmukaista toimintaa (Barkaoui 2010: 67; Kim 2015: 255). Lisäksi arvioitavan ominaisuudet voivat herättää erilaisia tunnetiloja tai jopa stereotypioita ja arvottamista (Brennan \& Brennan 1981; Nesdale \& Rooney 1996). Tällaiset affektiiviset tekijät ovat usein lähtöisin arvioijan subjektiivisista kokemuksista, ja ne saattavat olla hänelle itselleenkin tiedostamattomia. Affektiivisten tekijöiden merkitys ja voimakkuus vaihtelevat sen mukaan, miten ne ovat toiminnallisesti linkittyneet käsityksiin. (Pajares 1992: 318; Barcelos \& Kalaja 2011: 285-287.)

Arvioijien toimintaan pyritään vaikuttamaan tutkintojärjestelmissä eri tavoin, jotta laadukkaan arvioinnin (ks. Bachman 1990: 241; Weir 1990: 32; Brown 2004: 21-22) periaatteet toteutuvat. Arvioijien toiminnan yhdenmukaisuutta tuetaan arviointikoulutusten avulla (esim. Weigle 1994; Lim 2011; Attali 2016), selkeillä arviointikriteereillä ja niiden yhtenäisellä tulkinnalla (esim. Lumley 2002, 2005; Barkaoui 2010) ja arvioinnissa käytettävien tehtävien standardoinnilla (esim. Cizek \& Bunch 2007) sekä seuraamalla arvioijien ankaruutta tai lempeyttä ja johdonmukaisuutta (esim. Lumley 2005; Eckes 2008; Lim 2011). Tilastollisten menetelmien, kuten bias-analyysin, avulla voidaan lisäksi tarkastella arvioijien toimintaa suhteessa erilaisiin osallistujaryhmiin (esim. yhteinen ensikieli) tai jopa suhteessa yksittäisiin osallistujiin (Myford \& Wolfe 2003, 2004).

\section{Arvioijien käsityksiä vironkielisten suomenoppijoiden suullisesta kielitaidosta}

Tämä luku rakentuu seuraavasti: Alaluvussa 5.1 kuvaan ensin sitä, mistä arvioijat tunnistivat oppijoiden ensikielen ja millaisista käsityksistä arvioijien kommentit viestivät. En tarkastele artikkelissa ensikielen tunnistamiseen liittyviä perusteluja laajemmin fonologian, morfologian, semantiikan, syntaksin tai leksikologian näkökulmista enkä ota kantaa siihen, ovatko tuotoksiin liittyvät havainnot oikein tai väärin, vaan keskityn siihen, mitä kielenpiirteisiin liittyvät huomiot kertovat arvioijien kielitaitokäsityksistä. Alaluvussa 5.2 puolestaan esittelen tarkemmin neljä vironkielistä osallistujaa, joiden kautta syvennän analyysia niistä arvioijien käsityksistä, jotka liittyvät suulliseen kielitaitoon ja hyvän kielitaidon piirteisiin sekä siihen, miten ensikielen tunnistaminen vaikuttaa kielitaitoa koskeviin käsityksiin. Nämä neljä osallistujaa valitsin tarkastelun kohteeksi siitä syystä, että heistä kaksi lähes kaikki arvioijat tunnistivat vironkielisiksi, kun taas kahta muuta kaikki eivät tunnistaneet viroa ensikielenään puhuviksi.

\subsection{Vironkielisten suomenoppijoiden ensikielen tunnistaminen ja käsitykset kieli- taidosta}

Kaiken kaikkiaan arvioijat tunnistivat hyvin Rikkinäistä suomea -hankkeeseen osallistuneiden kymmenen vironkielisen ensikielen. Vastausten perusteella $76 \%$ arvioijista tunnisti joko varmasti tai melko varmasti heidät vironkielisiksi. Asetelmassa 1 on esitelty tyypillisimpiä arvioijien mainitsemia kielenpiirteitä, joihin he kertovat tunnistamisen perustuneen. 
Asetelma 1.

Vironkielisten oppijoiden tunnistaminen.

Intonaatio - Puhenuotti on hieman laulavampi kuin meillä ja siis melko virolainen

- Kohdekielenomainen intonaatio viittaisi viroon

- Intonaatio erittäin virolainen -laulavampi

Puherytmi $\quad$ Rytmi kuulostaa virolaiselta

- Luulen puhujan olevan vironkielinen, vaikka hän puhuukin melkein virheetöntä kieltä. Jotkut vokaalit, konsonantit ja sanavalinnat, rytmi tuovat mieleen viron.

- Puheen rytmi yhdistettynä suomen hyvään osaamiseen

- Hyvin luontevaa rytmiltään ja sanapainoiltaan

Sanasto - Vironkielinen sana joukossa

- Selvästi viron kielen sanastoa

- Sanat jotka menevät suomen kanssa sekaisin

- Luulen puhujan käyttäneen jopa vironkielisiä sanoja puheessaan, mitä vironpuhujat tekevät usein kompensoidakseen puutteellista sanavarastoaan

- Lyhennetyt sanat: kui, et, ei siit mitä, emänt, pihal

- Paljon sanastollista interferenssiä (kui 'kun', võtan 'otan', sööma 'syömään')

\begin{tabular}{|c|c|}
\hline Rakenteet & $\begin{array}{l}\text { - Rakenteissa on viron piirteitä } \\
\text { - Puheessa on joitakin rakenteita, jotka todennäköisesti virolle tyypil- } \\
\text { lisiä. } \\
\text { - Virolaiset pronominit ja konjunktiot ja mm. verbin taivutus } \\
\text { - Virolaisia rakenteita, mm. genetiivi ilman n-tunnusta, partitiivin } \\
\text { tunnuksena lyhyt vokaali } \\
\text { - Korjaa virolaisia rakenteita suomen rakenteisiin (itsekin > itsekään) } \\
\text { - On mukana rakenteita: käin, lastele }\end{array}$ \\
\hline $\begin{array}{l}\text { Vokaalien } \\
\text { ääntyminen }\end{array}$ & $\begin{array}{l}\text { - Sanan toisessa vokaalissa lyhentymää } \\
\text { - Vokaalien kestot } \\
\text { - Vokaalisointu oli hukassa joissakin sellaisissa sanoissa, jotka ovat } \\
\text { virossa muuten samoja kuin meillä, mutta ilman vokaalisointua } \\
\text { - Jälkitavujen vokaalit jäävät välillä lyhyiksi } \\
\text { - Pitkät vokaalit on lyhyempiä } \\
\text { - Vokaali(yhtymien) laveneminen } \\
\text { - Vokaalisoinnun puuttuminen } \\
\text { - Diftongien oikeneminen } \\
\text { - Loppuheitto } \\
\text { - Vokaalien putoaminen sanan lopusta }\end{array}$ \\
\hline $\begin{array}{l}\text { Konsonanttien } \\
\text { ääntyminen }\end{array}$ & $\begin{array}{l}\text { - Paikoin konsonanttien ääntämistä lievästi pidempänä } \\
\text { - Liudentuneet konsonantit } \\
\text { - Aavistuksen horjuntaa kestoissa (pitkät konsonantit lyhempiä) } \\
\text { - Konsonanttivaihtelun "virheet" kuulostavat virolaiselta } \\
\text { - Kaksoiskonsonanttien pituus } \\
\text { - t, d ja l äänne } \\
\text { - Geminaattojen lyheneminen, esim. parvekkeela, niile } \\
\text { - Virolainen äng-äänne (kenengän = kenenkään) } \\
\text { - k-äänne on joskus liian "pehmeä" } \\
\text { - Liudentunut l }\end{array}$ \\
\hline
\end{tabular}


Edellä esitetyistä huomioista on havaittavissa, että arvioijat löysivät oppijoiden puheesta useita vironkielisyyteen viittaavia vihjeitä. Tunnistaminen tapahtui yleensä yksittäisten kielellisten vihjeiden perusteella (ks. esim. 1-3), kuten vironkielisen sanan, suomen kielestä poikkeavan rakennemuodon tai ääntämisessä havaitun vierasperäisen piirteen perusteella.

(1) Siellä oli kerran -kin kun olisi pitänyt olla -kaan.

(2) Ei mitään kovin selviä virolaisuuksia mutta oli siellä "tegemisiä" ja "terve" kuulosti alussa kovin virolaiselta.

(3) d:n ääntyminen hieman t:n kaltaisena kuitenkin viittaisi etelänaapuriimme.

Arvioijien mainitsemat vironkielisyyteen viittaavat piirteet ovat tyypillisiä vironkielisten oppijoiden vaikeuksia suomen kielessä. Esimerkiksi Kaivapalu (2005, 2009) on havainnut vironkielisten kielenkäytössä vastaavia piirteitä tutkiessaan viron vaikutusta suomen oppimiseen. Arvioijien tekemät havainnot ovat myös samankaltaisia kuin Jääskeläisen (2002) tutkimuksessa, jossa tarkastellaan vironkielisten äännevariaatiota puhesuomessa.

Vaikka lähdekielen vaikutuksesta aiheutuneet piirteet olivat varsin mitättömiä vuorovaikutuksen ja kielen toiminnallisuuden näkökulmasta, arvioijat löysivät niitä lähes kaikkien vironkielisten tuotoksista. Arvioijien varsin tarkat kuvaukset lähdekielen vaikutuksesta kertovat lähdekielen piirteiden tunnistamisen helppoudesta, ja he käyttivätkin huomioissaan usein vahvaan tunnistamiseen liittyviä ilmaisuja: melko virolaista, erittäin virolainen intonaatio, helppo tunnistaa virolaiseksi, melko paljon vironomaista siirtovaikutusta, vahva viron kielen vaikutus. Tunnistaminen on yhteydessä siihen, että useat arvioijat ovat suomen opintojen yhteydessä opiskelleet viroa ja siten osasivat yhdistää tietyt kielenpiirteet vironkielisiin oppijoihin. Huomioissaan arvioijat ilmaisivat teoreettisten opintojensa ja myös työkokemuksensa kautta muodostuneita käsityksiään, jotka usein muokkaantuvat henkilökohtaisiksi käsityksiksi omien kokemusten ja tietorakenteiden kautta (Woods \& Çakir 2011: 387-389).

Arvioijat nimittivät usein vironkielisten tuotoksissa ilmenneitä puutteita lipsahduksiksi. Lipsahduksilla viitattiin yksittäisiin puutteisiin tuotoksissa, mutta viittauksilla lipsahduksiin myös korostettiin vironkielisten hyvää suomen taitoa. Jos kielitaidon taso ei vastannut odotuksia, tämä oli yllätys - ja jopa pettymys, kuten seuraavista esimerkeistä voi havaita.

(4) Sanavaraston luulisin olevan laajempi. Mietin, että enhän anna liian hyvää arvosanaa siksi, että virolainen oppii ehkä nopeammin suomea.

(5) Heikko suoritus virolaiselta, viesti tulee kuitenkin ymmärretyksi.

(6) Virolaisen arviointi on hankalaa, koska virolaisuuksista ei haluaisi rangaista, jos on ymmärrettävää. 
Arvioijien huomiot viestivät kielitaidon tasoon liittyvistä odotuksista, jotka ovat yhteydessä kielten geneettiseen ja typologiseen läheisyyteen ja siihen liittyvään kielenhallinnan helppouteen. Lähde- ja kohdekielen typologiset yhtäläisyydet eivät aina kuitenkaan tarkoita kielen oppimisen helppoutta. (Kaivapalu 2005: 26; Sulkala 1996.) Vironkieliset toki hallitsevat ensikielensä perusteella monia suomen kielen piirteitä, mutta lähisukukielisyydestä on enemmän hyötyä kielen vastaanottamisessa ja ymmärtämisessä kuin tuottamisessa (Kaivapalu mp.).

Ensikielen tunnistamisella näyttää edellä esitettyjen huomioiden valossa olevan yhteyksiä käsityksiin kielitaidosta. Huomioita tukevat Rikkinäistä suomea -hankkeessa tehdyt tilastolliset analyysit (kuvio 1). Analyyseissa tutkittiin kolmen tekijän (äidinkieli, tunnistaminen ja arviointikriteerit) yhdysvaikutusta Facets-ohjelman MFRMmallin (Many-Facets Rasch Measurement) avulla (ks. Linacre 2009). Kuviossa on merkitty yhtenäisillä mustilla viivoilla välille raja-arvot ( 2 ja -2$)$, joiden ylä- tai alapuolelle jäävät kriteerit ovat tilastollisesti merkitseviä.
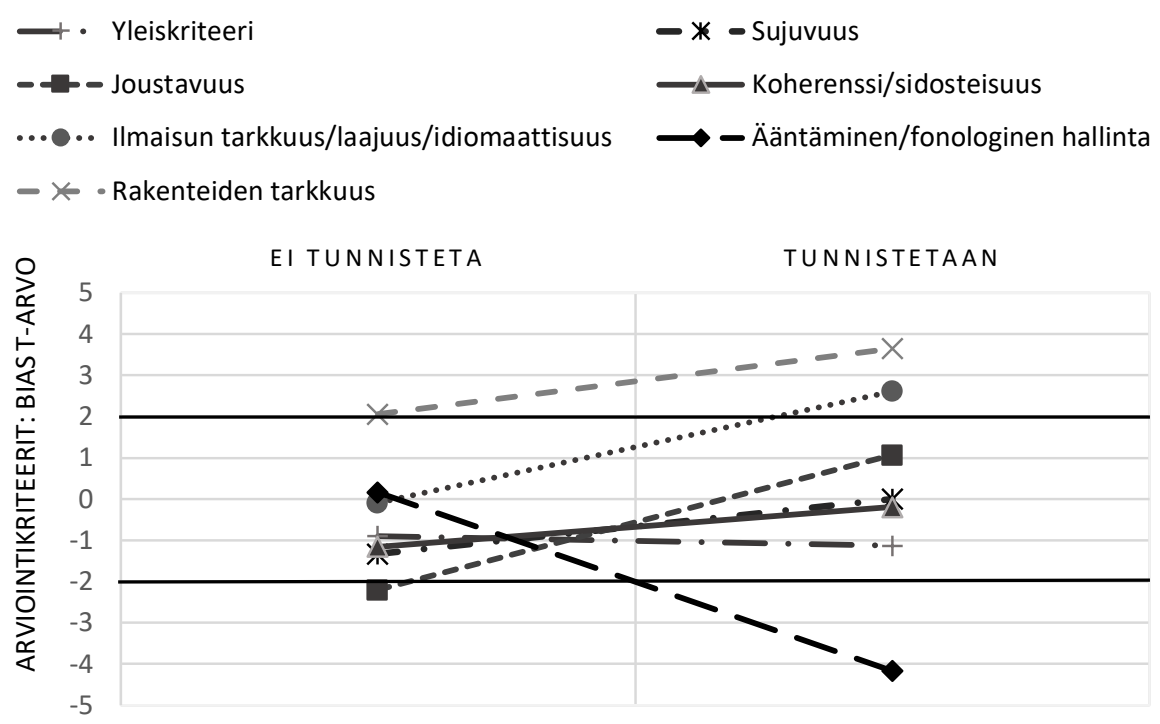

Kuvio 1.

Ensikielen tunnistamisen vaikutus kielen piirteiden taitotasoarvioihin.

Kuviosta 1 on havaittavissa, että vironkieliseksi tunnistetut saivat tunnistamattomia hieman paremmat arviot ilmaisun tarkkuudesta, laajuudesta ja idiomaattisuudesta (sanasto) sekä rakenteiden tarkkuudesta mutta huonommat arviot ääntämisen ja fonologian hallinnasta. Näiden yksittäisten kriteereiden arvioilla ei ollut vaikutusta oppijoiden saamaan kielitaidon yleistaitotasoarvioon. Tulokset viittaavat kuitenkin siihen, että arviointitilanteessa tunnistaminen vaikuttaa arvioijien käsityksiin joidenkin yksittäisten kielen piirteiden osalta.

Yksi selitys siihen, miksi vironkieliseksi tunnistettuja palkittiin rakenteiden ja sanaston hallinnasta, on oppijoiden kielitaidon taso. Eckes (2008: 180; ks. myös Pollitt \& Mur- 
ray 1996) on havainnut oppijan kielitaitotason ohjaavan arviointia. Taitotaso vaikuttaa siihen, mihin kielen piirteisiin arvioijat keskittyvät oppijoiden tuotoksissa. Koska ylemmillä taitotasoilla ilmaisun (sanaston) tarkkuus, laajuus ja idiomaattisuus sekä rakenteiden tarkkuus korostuvat (Eurooppalainen viitekehys 2003), myös arvioinnissa näihin piirteisiin kiinnitetään enemmän huomiota. Lisäksi taustalla voivat vaikuttaa arvioijien käsitykset sanaston ja rakenteiden hallinnan tärkeydestä, jolloin he herkästi perustavat arvionsa näiden piirteiden hallintaan (Brown, Iwashita \& McNamara 2005; Bøhn 2015: 8).

Ilmaisun tarkkuuden, laajuuden ja idiomaattisuuden sekä rakenteen tarkkuuden hyviä taitotasoarvioita tukivat arvioijien huomiot sujuvista ja luontevista tuotoksista. Sujuvuus yhdistyy usein kielen tuottamisen helppouteen, mutta se liitetään myös sanaston ja rakenteiden monipuolisuuteen ja kompleksisuuteen (Chambers 1997: 535, 543). Vironkielisten puhuma suomi kuulostaa usein varsin kohdekielenomaiselta, vaikka oppijan tuotoksessa olisikin paljon oman lähdekielen vaikutusta. Tuotosten sujuvuus vahvistaa vaikutelmaa hyvästä kielitaidosta, ja sitä kautta se voi vaikuttaa käsityksiin sanaston ja rakenteiden hyvästä hallinnasta.

Arvioijien mukaan oppijoiden satunnaiset puutteet eivät heikentäneet tuotoksen ymmärrettävyyttä. Ymmärrettävyys on kuitenkin varsin monisyinen ilmiö, koska siihen vaikuttavat kielen eri piirteiden lisäksi muiden muassa tehtävän aihepiiri ja oppijan ensikielen tuttuus. Usein hyvään ymmärrettävyyteen yhdistetään sanastollinen ja rakenteellinen tarkkuus (Isaacs \& Trofimovich 2012: 484, 491, 497), mikä arvioijien kirjallisten huomioidenkin perusteella vahvisti vironkielisten oppijoiden tuotosten ymmärrettävyyttä. Tämä yhteys näkyi myös oppijoille annetuissa taitotasoarvioissa.

Vironkielisten oppijoiden ääntämisen ja fonologian hallinta arvioitiin muita analyyttisia kriteereitä heikommaksi (ks. kuviota 1). Tulos on yllättävä, koska ensikielen tuttuus on yleensä yhteydessä parempiin arvioihin ääntämisestä (Carey ym. 2010: 215). Lisäksi kirjalliset huomiot eivät tukeneet annettuja arvioita, koska niissä arvioijat kuvailivat vironkielisten ääntämistä usein kohdekielenomaiseksi ja heidän taitoaan verrattiin jopa natiivikielenpuhujiin.

Arvioijien mielestä ääntämisen ja fonologian hallinnan arviointia vaikeuttivat Ykin arviointikriteerit, jotka eivät ole tämän kriteerin osalta tarpeeksi yksityiskohtaiset kielitaidon ylemmillä taitotasoilla. Ehkä tämän vuoksi he kuvasivat fonologisten ansioiden ja puutteiden rinnalla myös monia muita tuotoksissa esiintyviä piirteitä: puheessa esiintyviä taukoja, epäselvää puhetapaa, puheen hitautta, äänenkorkeutta ja suomen kielen murteelta kuulostavaa kieltä. Edellä mainitut piirteet liittyvät enemmän oppijan persoonaan ja puhumisen tapoihin kuin ääntämisen ja fonologian hallintaan, mutta näillä vaikutti olevan merkitystä määriteltäessä tämän taitoa ääntää suomea.

Käsitykset ääntämisen hyvyydestä ja heikkoudesta sekä ymmärrettävyydestä ovat hyvin henkilökohtaisia (ks. Munro \& Derwing 1995). Lisäksi jos oppijan ensikieli tunnistetaan, se herättää kuulijoissa erilaisia mielikuvia ja stereotypioita, jotka vaikuttavat kielitaidosta tehtyihin arvioihin, ennen kaikkea ääntämisen arvioihin (Kang 2008: 186). Arvioijien huomiot tunnistettavista vironkielisistä piirteistä ääntämisessä, kuten vironkielisestä intonaatiosta, puherytmistä ja aksentista, kielennettiin puutteiksi, vaikka muuten oppijoiden tuotoksia kiiteltiin. Oppijat tunnistettiin yleensä juuri ääntämisestä vieraskielisiksi, mikä todennäköisesti vaikutti käsityksiin ääntämisen heikkou- 
desta verrattuna muihin kielitaidon piirteisiin. Nämä löydökset viittaavat edellä mainittujen tutkimusten ohella siihen, että lähdekielen tunnistaminen vaikuttaa arviointiin ja kielitaidosta tehtäviin päätelmiin.

\subsection{Neljän vironkielisen oppijan suomen kielen taito}

Seuraavaksi esittelen neljä vironkielistä oppijaa tarkemmin: kaksi parhaiten ja kaksi heikoiten vironkieliseksi tunnistettua. Olen antanut heille seuraavat pseudonyymit: kaksi parhaiten tunnistettua vironkielistä ovat miehiä, Mati ja Heiki, ja kaksi heikoiten tunnistettua puolestaan naisia, Maria ja Julia. ${ }^{2}$

Taulukossa 1 on esitetty, kuinka monta prosenttia arvioijista tunnisti Matin ja Heikin vironkieliseksi ja mille taitotasolle (1-6) he määrittelivät näiden kielitaidon (yleistaitotaso = holistinen arvio suorituksesta). Lisäksi taulukossa on muutamia lainauksia arvioijien kirjoittamista huomioista. Annetut taitotasoarviot linkittyvät Eurooppalaiseen viitekehykseen seuraavasti: $1 \approx \mathrm{A}_{1}, 2 \approx \mathrm{A} 2,3 \approx \mathrm{B}_{1}, 4 \approx \mathrm{B} 2,5 \approx \mathrm{C}_{1}$ ja $6 \approx \mathrm{C}_{2}$.

Matin paljasti vironkieliseksi kaksi sanaa: työkaveri, joka kuultiin sanana töökaveri, ja sanalipsahdus sõbrad, jonka hän korjasi varsin pian suomenkieliseksi sanaksi (ks. liite). Lisäksi arvioijat raportoivat hänellä olevan liian liudentunut (palatalisoitunut) l-äänne sanassa kalja, jotta hänen ensikielensä voisi olla suomi. Kuten alla olevista arvioijien huomioista on havaittavissa, arvioijat kuitenkin pitivät Matin suomen kieltä varsin sujuvana, luontevana ja lähes äidinkielenomaisena.

(7) On käyttänyt varmaan suomea jo kauan arkielämässä.

(8) Lausepainossa omaksunut suomalaisen duunarin elkeitä.

(9) On ehkä lapsena kuullut/puhunut suomea.

(10) Puhuja on ollut pitkään työssä Suomessa, koska perhekin on täällä.

Arvioijien kielitaidon kuvailuihin liittyi myös arviointikriteereiden ulkopuolisia tekijöitä. Matin kielitaidon taitotaso kertoi arvioijien mielestä pidempiaikaisesta oleskelusta ja asumisesta kohdekielisessä ympäristössä sekä suomen kielen käytöstä koti- ja työkielenä. Nämä arvioijien varsin pitkälle viedyt tulkinnat oppijan kielitaidon taustalta löytyvistä tekijöistä ovat yhteydessä Matin tuotoksen sisältöön: pari kaverii joka kene kanssa kat me yleensä kat niinku viikonloppuna saunottaan tai jotai semmost (.) pari työkaveria vielt kenen kanssa kato otetaa muutama kalja joskus (.) kylässä jutellaan kat ihan mistä vaan kat. Huomioillaan arvioijat viestivät koulutuksen ja työn kautta omaksuttuja kielenoppimiseen liittyviä käsityksiään: hyvä kielitaito saavutetaan kohdekielisessä ympäristössä, ja aktiivinen kielenkäyttö ja vuorovaikutustilanteet kohdekielisten kanssa edistävät kielen oppimista. Lisäksi arvioijat viittasivat työskentelyyn Suomessa, millä korostettiin työssä tarvittavan kielenkäytön merkitystä kielitaidon kehittymisessä.

2. Näiden oppijoiden tuotokset ovat liitteessä. 
Taulukko 1.

Vironkieliseksi tunnistetut oppijat.

\begin{tabular}{|c|c|c|c|}
\hline $\begin{array}{l}\text { Oppijan } \\
\text { pseudo- } \\
\text { nyymi }\end{array}$ & $\begin{array}{l}\text { Tunnistaneiden } \\
\text { arvioijien osuus }\end{array}$ & $\begin{array}{l}\text { Yleistaitotaso } \\
\text { (osuus } \\
\text { arvioijista) }\end{array}$ & Huomioita suorituksesta \\
\hline Mati & $86 \%$ & $\begin{array}{l}3(5 \%) \\
4(43 \%) \\
5(34 \%) \\
6(18 \%)\end{array}$ & $\begin{array}{l}\text { - Puhuu sujuvasti, luontevasti ja spon- } \\
\text { taanisti, tosin eräänlaista kait-kieltä, } \\
\text { kun joka toinen sana on kait/kat. } \\
\text { - Hyvin sujuva, aiheen käsittely moni- } \\
\text { puolinen, ääntäminen hyvä, rakenteet } \\
\text { hallussa, melko lailla jo idiomaattista- } \\
\text { kin. } \\
\text { - Puhuu sujuvasti. Puheessa häiritsee } \\
\text { joka sanan loppuun tuleva -ka(t), voi } \\
\text { olla rakenteellinen puheen häiriö tai } \\
\text { viron -ga vaikkei se joka sanaan siellä } \\
\text { tule. Erittäin sujuvaa ja monipuolista } \\
\text { jokapäivän puhetta. } \\
\text { - Kuulee kyllä hienon hienosti, että hä- } \\
\text { nen äidinkielensä ei ole suomi, mutta } \\
\text { puhe on hyvin luontevaa ja sujuvaa. } \\
\text { - Harkitsin ylempääkin arvosanaa, } \\
\text { mutta äidinkielen käyttäminen toistu- } \\
\text { vasti apuna (yleiskriteerit), vaikuttaa } \\
\text { siihen, että päädyin kolmoseen. }\end{array}$ \\
\hline Heiki & $92 \%$ & $\begin{array}{l}3(5 \%) \\
4(41 \%) \\
5(46 \%) \\
6(9 \%)\end{array}$ & $\begin{array}{l}\text { - Hienoa sanastoa ja idiomaattista tuo- } \\
\text { tosta. } \\
\text { - Puhe on todella idiomaattista, su- } \\
\text { juva ja vahvasti puhekielistä; annoin } \\
\text { 4-tason, koska epäilen, että puhuja ei } \\
\text { pystyisi varioimaan puhettaan tilan- } \\
\text { teen mukaan. } \\
\text { - Ääntäminen hyvin suomalaista. } \\
\text { - Vaikea arvioitava virolaisten piirteiden } \\
\text { vuoksi. Koska niitä vain kohtuullisesti, } \\
\text { annan viisi. Niitä ei myöskään ole sa- } \\
\text { naston tasolla vaan esimerkiksi loppu- } \\
\text { heittoina ja intonaatiossa. } \\
\text { - On se niin lähellä suomea... } \\
\text { - On hyvä, mutta vähän vironkielistä. } \\
\text { lipsuilua, ja siksi en anna kuutosta. } \\
\text { - Ilmaisu on luontevaa, sujuvaa ja spon- } \\
\text { taanin tuntuista. Laaja sanasto, into- } \\
\text { naatio ja lausepaino kohdallaan, ra- } \\
\text { kenteet virheettömiä. }\end{array}$ \\
\hline
\end{tabular}

Matin kielitaidon vahvuudeksi mainittiin ennen kaikkea sujuvuus. Tuotoksen yleistaitotasoa kuitenkin laski lauseiden lopussa kuuluva -kat:

(11) Erikoinen täytesana 'kat' 'kät' häiritsee ymmärrettävyyttä. Muuten idiomaattinen, luonteva puhuja. 
(12) Se kat siellä välissä häiritsi, mutta niinkutteli, kuten monet suomalaisetkin.

(13) Selkeä, mutta häiritsevänä kait-tyyppinen lisäys lähes jokaisen lauseen lopussa.

(14) Joka väliin tunkee "kait"-ilmaisun? Voisi olla ylintäkin tasoa, jos tuo välisana jäisi pois.

(15) Olisi voinut antaa kutosenkin, mutta siinä on kuitenkin tuo epäsuomalainen "kat".

Arvioijat yhdistivät sanan viron kielen komitatiiviin - $g a$, mutta se kuultiin puheesta varsin eri tavoin, esimerkiksi kat, kät, kait, köt, kato, gat, kayt, et. Tällainen yllättävä ja outo aines suullisessa tuotoksessa häiritsi arvioijia, ja sen vuoksi he näkivät tuotoksessa puutteita ilmaisun ja rakenteiden tarkkuudessa.

Heikin puolestaan paljasti vironkieliseksi intonaation ja loppuheittojen lisäksi se, että hän äänsi t:n puolipitkänä (86-vuottinen) ja käytti konjunktion kun sijaan vironkielistä vastinetta kui. Kuten seuraavista kommenteista voi havaita, edellä mainituista syistä miehen puhe kuulosti arvioijista lounaismurteelta.

(16) Turun seudulla korvakuulolta suomen oppinut virolainen.

(17) Äidinkielinen länsisuomalainen puhuu samaan tapaan.

(18) Voisi olla myös Suomen murretta, varsinaissuomalaista murretta.

(19) Varsinais-Suomalaisen korviin oikein tuttua murretta.

(20) Lounaismurteisuus vahvaa.

(21) Menisi melkein suomalaisesta lounaismurteita puhuvasta henkilöstä.

Puhetta luonnehdittiin hyvin suomalaiseksi, vaikkakin murteelliseksi. Yleensä murteen käyttäminen on merkki jo varsin hyvästä kielitaidosta ja myös siitä, että oppija on kielellisesti integroitunut murrealueelle ja että hän hallitsee puhekielen hyvin. Arvioijat kuitenkin pitivät murteellisia muotoja "virheinä" ja oppijan kielitaidon heikkouksina. Vaikka puhekielen hallintaa pidetään tärkeänä jokapäiväisen elämän kielenkäyttötilanteissa, arvioijien huomioista välittyy yleiskielen arvostus. Yleiskielen arvostus on yhteydessä kirjoittamisen taidon arvostukseen, koska hyvää kirjoittamisen taitoa pidetään yleensä hyvän kielitaidon mittarina ja yleiskielen normit sisäistäneitä kielenkäyttäjiä kielellisesti lahjakkaita. (Dufva, Alanen \& Aro 2003: 309.)

Vertaaminen äidinkielisten kielitaitoon kuvastaa sitä, että arvioijat pitivät äidinkielisyyttä tavoitetasona. Taitotason $6\left(\approx \mathrm{C}_{2}\right)$ saavuttaminen edellyttää huomioiden perusteella oppijoilta sujuvan, luontevan ja suomalaisen puhetavan lisäksi selkeiden 
vieraskielisten piirteiden puuttumista. Ääntämisen ja fonologian hallinnan kriteerissä vaatimustaso tuntui nousevan, kun oppijalla oli hyvä kielitaito. Tällöin arvioijat usein vertasivat oppijan suullista tuotosta ja ääntämistä äidinkielisten puhujien tuotoksiin (vrt. esim. Carey ym. 2010: 204; ks. myös Best, McRoberts \& Goodwell 2001). Viittaukset äidinkielisyyteen ovat yllättäviä siksi, että arviointia ohjaavien kriteereiden ja Eurooppalaisen viitekehyksen ylimmällä taitotasollakin (Yki $6 \approx \mathrm{EVK} \mathrm{C}_{2}$ ) kuvataan toisen ja vieraan kielen oppijan taitoa, ei syntyperäisen kielitaitoa (Eurooppalainen viitekehys 2003: 47, 63).

Heikiin liittyvissä huomioissaan arvioijat kuvasivat myös miehen persoonaa ja tapaa puhua (esim. 22-24). Hänen puhetapaansa luonnehdittiin rauhalliseksi, ja häntä pidettiin hitaana puhujana ja harvasanaisena. Nämä edellä mainitut piirteet yhdistettiin huomioissa suomalaisten miesten tapaan puhua.

(22) Mies, joka sanoo vain tarpeellisen lavertelematta.

(23) Tämä voisi olla hämäläissyntyinen mies, hidas ja juro, mutta mukava.

(24) Puhuu kuin suomalainen, rauhallinen puhuja.

Käsityksiin kielitaidosta vaikuttaa kytkeytyvän oppijoiden henkilökohtaisia ominaisuuksia, kuten tapa puhua ja ääntää suomea. Arvioijien kielentämät huomiot ovat esimerkkejä myös siitä, että affektiivisilla tekijöillä on merkitystä kielitaitokäsityksissä. Hitaasti puhuvat suomalaismiehet yhdistyivät arvioijien omiin subjektiivisiin käsityksiin suomalaisten miesten tavoista puhua, mutta samalla huomioissa on nähtävissä historiallisesti, kulttuurisesti ja sosiaalisesti muodostuneita käsityksiä suomalaisten miesten kommunikointitavoista.

Taulukossa 2 (seur. sivulla) on esitelty kaksi vironkielistä naista, jotka tunnistettiin vironkielisiksi huonoiten. Vain vähän yli puolet (52\%) arvioijista tunnisti heidän ensikielensä. Marian ensikieleksi ehdotettiin espanjaa tai venäjää. Hänen ensikielensä tunnistamista vaikeutti se, että hänen ääntämisensä oli selkeää ja kohdekielenomaista eikä siinä ollut selviä merkkejä lähtökielestä. Eräs arvioija totesikin, että "äännerakenne on melko lähellä suomea, koska ei ollut mitään selkeitä ääntämisvirheitä”. Julian lähtökieltä ei puolestaan osattu mainita lainkaan tai sitten hänen arveltiin olevan venäjänkielinen tai taustaltaan inkerinsuomalainen.

$\mathrm{Ne}$ arvioijat, jotka tunnistivat Marian vironkieliseksi, totesivat tunnistaneensa ensikielen intonaatiosta ja pehmeästä $l$-äänteestä sekä siitä, että hän käytti yhdessä sanassa $d$-äänteen sijasta $t$ :tä (vaihtamme). Vaikka Marian ääntämistä pidettiin hyvänä ja tuotosta sujuvana, hänen kielitaitonsa sijoitettiin taitotasolle $4(\approx \mathrm{B} 2)$. Oppijan kielitaidon puutteina pidettiin liian konkreettista ja suppeaa sanastoa ja lisäksi tavallisempien rakenteiden hallinnassa havaittiin puutteita. Osalla arvioijista oli kuitenkin myös vastakkaisia käsityksiä oppijan taidosta: "puhuu suhteellisen sujuvasti ja hallitsee rakenteet", "sujuva ja monipuolinen ilmaisu, laaja sanasto", "riittävä sanasto, joten ilmaisee sanottavansa melko tarkasti ja yksityiskohtaisesti”. 
Taulukko 2.

Ei-vironkieliseksi tunnistetut oppijat.

\begin{tabular}{|c|c|c|c|}
\hline $\begin{array}{l}\text { Oppijan } \\
\text { pseudo- } \\
\text { nyymi }\end{array}$ & $\begin{array}{l}\text { Tunnistaneiden } \\
\text { arvioijien osuus }\end{array}$ & $\begin{array}{l}\text { Yleistaitotaso } \\
\text { (osuus } \\
\text { arvioijista) }\end{array}$ & Huomioita suorituksesta \\
\hline Maria & $52 \%$ & $\begin{array}{l}2(2 \%) \\
3(11 \%) \\
4(68 \%) \\
5(18 \%)\end{array}$ & $\begin{array}{l}\text { - Sujuva ja melko laajasti aihetta käsit- } \\
\text { televä tuotos. Pitkät tauot harvinaisia, } \\
\text { mutta rakenteissa jonkin verran pie- } \\
\text { niä puutteita. } \\
\text { - Puheessa oli korkeammankin tason } \\
\text { piirteitä, mutta tässä näytteessä sa- } \\
\text { nasto oli melko yksinkertaista. } \\
\text { - Sanasto on melko niukka. } \\
\text { - Pieniä epätarkkuuksia perus- } \\
\text { sanastossa eikä paljon variaatiota } \\
\text { rakenteissa. } \\
\text { - Rakenteissa on horjuntaa sen ver- } \\
\text { ran, etten kuitenkaan rohkene antaa } \\
\text { enempää. } \\
\text { - Sujuvaa mutta rakenteet haparoivaa. } \\
\text { - Sujuva ja luonteva, mutta ilmaisun } \\
\text { tarkkuus ja rakenteet ovat kuitenkin } \\
\text { vielä keskitasoa. }\end{array}$ \\
\hline Julia & $52 \%$ & $\begin{array}{l}2(5 \%) \\
3(52 \%) \\
4(34 \%) \\
5(7 \%) \\
6(2 \%)\end{array}$ & $\begin{array}{l}\text { Puhujaa on hankala arvioida, koska } \\
\text { puheenvuoro on epäyhtenäinen ja } \\
\text { tauot tosi pitkiä. } \\
\text { - Pitkien taukojen jälkeen tuotetut lau- } \\
\text { seet olivat kuitenkin yllättävän moni- } \\
\text { puolisia sekä rakenteeltaan että sa- } \\
\text { nastoltaan. } \\
\text { - Kohdekielenomaista, mutta } \\
\text { suppeahko tuotos. Vähäisiä raken- } \\
\text { teellisia puutoksia. Hetkittäin to- } \\
\text { della idiomaattista. Todella hankala } \\
\text { arvioida. } \\
\text { - Hidas puherytmi alensi arviointia, } \\
\text { paikoin tarkka. } \\
\text { - Paljon pitkiä taukoja, mutta ne eivät } \\
\text { vaikuta johtuvan puheen muotoiluun } \\
\text { liittyvistä ongelmista. } \\
\text { Minusta melko hyvä esimerkki niu- } \\
\text { kahkosta kolmosesta: vähän, luettelo- } \\
\text { maista asiaa. }\end{array}$ \\
\hline
\end{tabular}

Arvioijien ristiriitaiset näkemykset Marian sanaston riittävyydestä ja laajuudesta ja rakenteiden hallinnasta viestivät erilaisista käsityksistä siitä, mitkä piirteet suullisessa kielitaidossa - tai yleensä kielitaidossa - ovat keskeisiä, mikä sanaston ja rakenteiden oppimisjärjestys on ja kuinka arviointia ohjaavat kriteerit tulkitaan. Arvioijien keskuudesta voidaan löytää erilaisia arvioijatyyppejä sen mukaan, mitä kriteereitä he käyttävät arvioinneissaan. Esimerkiksi Eckes (2008: 177-178) löysi arvioijien toimintaa tutkiessaan arvioijatyyppejä, jotka perustivat arviointinsa pääasiassa yhteen kriteeriin tai jotka jättivät tietyn kriteerin arvioinnissaan kokonaan huomioimatta. Eckesin 
tutkimustulokset vahvistavat käsityksiä siitä, että eri kielenpiirteiden arvostus ohjaa arvioijien toimintaa arviointitilanteessa ja että arvioinnin taustalla vaikuttavat yksilölliset ja suhteellisen pysyvätkin käsitykset kielitaidosta.

Ristiriitaisuuksia arvioinnissa selittävät myös erilaiset tulkinnat arviointikriteereiden sisällöistä (Barkaoui 2010: 55). Arviointikriteereissä mainittujen määritelmien, kuten jokseenkin luontevasti ja sujuvasti tai suhteellisen sujuvasti, välinen ero on usein hiuksenhieno. Arvioijat käyttivät huomioissaan näitä määritelmiä, mutta todennäköisesti niiden merkityksissä oli arvioijakohtaista vaihtelua. Lisäksi arvioijien kommenteista voi päätellä, että heillä on käsityksiä siitä, mitkä suomen kielen sanat ja rakenteet on hallittava tietyillä taitotasoilla: "liian vähän variaatiota rakenteissa, rakenteet ovat vielä keskitasoa ja epätarkkuuksia perussanastolla". Huomioissaan arvioijat toistavat niin sanotussa asiantuntijakontekstissa omaksumiaan käsitteitä ja arvostuksia, jotka pohjautuvat oppikirjojen, opetusmateriaalin ja opetussuunnitelman sekä muiden opettajien käsityksiin oppimisjärjestyksestä (Dufva ym. 2003: 305). Etenkin rakenteita ja sanastoa usein lähestytään oppikirjojen perusteella rakennettujen käsitysten kautta ja erotellaan helpot ja vaikeat rakenteet tai yleiset ja harvinaiset sanat. (Esim. Gass \& Selinker 2001: 311-315; Salo 2006: 238-240.)

Marian tavoin Julian tunnisti vironkieliseksi $52 \%$ arvioijista. Yksittäiset kohdat puheessa paljastivat hänen olevan vironkielinen: naine ja en ma koskaan mitää pyytä. Toisaalta tarkkaan kuunnelleet arvioijat olivat myös havainneet puheessa "tyypillisiä virolaisuuksia", kuten pitkien vokaalien (tavatan) ja geminaattojen (parvekkeela) lyhenemistä.

Julian tuotoksen arviointi koettiin vaikeaksi. Tuotosta pidettiin hyvin epätasaisena, koska kielen eri piirteiden taitotaso vaihteli. Julia hallitsi hyvin ääntämisen, ja tuotos oli rakenteellisesti tarkkaa, mutta puheenvuorossa oli pitkiä taukoja eikä tuotosta ollut paljon. Tämän vuoksi arvioijat antoivat hänelle koherenssista, sujuvuudesta ja joustavuudesta muita kriteereitä heikommat taitotasoarviot.

Sujuvuus oli varsin tyypillinen ja usein käytetty ilmaisu, jolla vironkielisten suorituksia kuvattiin. Vaikka arvioijien käsitykset oppijoiden kielitaidon tasosta vaihtelivat, kirjallisissa huomioissa vironkielisten tuotoksia kuitenkin kuvailtiin "melko sujuviksi" tai "sujuviksi" tai jopa "hyvin sujuviksi". Sujuvuudella arvioijien huomioissa viitattiin tavallisesti puhenopeuteen, tuottamisen helppouteen tai ääntämisen selkeyteen, mutta se liittyi myös kielen luontevaan käyttöön (Chambers 1997: 535-538). Arvioijat yhdistivät sujuvuuteen kielen luontevuuden ja tuottamisen helppouden etenkin silloin, kun oppijan kielitaito oli hyvä (esim. Heiki ja Mati). Jos kielitaidossa nähtiin kuitenkin puutteita, sujuvuuden määritelmään vaikuttivat muut piirteet. Marian kohdalla arvioijat viittasivat usein tuottamisen helppouteen: "puhetta oli helppo seurata ja ymmärtää ja sujuvaa ja vaivattomalta kuulostavaa suomea", mutta sujuvuutta häiritsivät puutteet sanastossa ja rakenteissa. Juliaa taas kiiteltiin ääntämisen ja sanaston sekä rakenteiden tarkkuuden hallinnasta, mutta tuotosta ei pidetty kovin sujuvana puhejakson aikana ilmenneiden taukojen vuoksi:

(25) Irrallisia ajatuksia kuin mietelauseita. Rakenteet oikein.

(26) Puhuu vain irrallisia pätkiä, jotka kuitenkin erillisinä kuulostavat hyviltä. 
Suullisessa tuotoksessa tauot yleensä huomataan helposti, ja niiden määrä ja pituus vaikuttavat siihen, milloin puhe määritellään sujuvaksi tai epäsujuvaksi. Erilainen puhenopeus ja tauot kuuluvat myös äidinkieliseen puheeseen, mutta sujuvuuteen tauot vaikuttavat häiritsevästi, jos ne eivät ole kielen rakenteen kannalta luonnollisissa kohdissa tai niitä esiintyy usein. (Chambers 1997: 539.) Julian puheessa oli paljon pitkiäkin taukoja yksittäisten lauseiden sisällä. Tästä syystä sujuvuuteen yhdistyivät puutteet koherenssissa, koska tuotos ei kuulostanut arvioijista yhtenäiseltä kokonaisuudelta, vaikkakin kielellisesti lauseet olivat varsin luontevia ja kohdekielen mukaisia. Yksi arvioija totesikin, että "puhuja pitää hiukan liian pitkiä taukoja, joten puhe ei tunnu kovin sidosteiselta, vaikka todellisuudessa puhuja kyllä hallitsee ja käyttää erilaisia sidoskeinoja ihan oikein. Kaiken kaikkiaan puhe kuitenkin luontevaa ja vaivattoman tuntuista”.

\section{Pohdintaa}

Ensikielen tunnistamisella näyttää olevan merkitystä arviointikäyttäytymiseen. Ensikieleen liittyvät kokemukset ja kohdekielen oppijoihin liittyvät subjektiivisetkin käsitykset ohjaavat arvioijien toimintaa ainakin jossain määrin. Vironkielisten suomenoppijoiden kielitaitoon liittyy odotuksia, jotka aktivoituvat arvioijan tunnistaessa puhujan ensikielen. Kielitaidon taitotason odotetaan olevan jo varsin hyvällä tasolla ja oppijoiden hallitsevan vaivatta oman lähdekielensä kautta kohdekielen sanaston ja rakenteet.

Vironkielisten kielitaidon arvioihin liittyy vahvasti sujuvuuden käsite. Tämä havainto on yhteydessä siihen, että arvioitaessa taitotasoltaan hyvien oppijoiden kielitaitoa sujuvuuden kriteerin merkitys yleensä korostuu (esim. Sato 2011: 237). Mielenkiintoista käsitysten näkökulmasta kuitenkin on se, että vaikka arvioijat mainitsivat sujuvuuden usein, analyyttisten kriteereiden taitotasoarvioissa sujuvuus ei näyttäytynyt muita kriteereitä merkitsevämpänä. Tästä syystä voidaankin olettaa, että arvioijille sujuvuuden kriteeri on merkitykseltään paljon laajempi kuin Ykin arviointikriteereissä kuvattu sujuvuuden kriteeri. Vironkielisten oppijoiden kohdalla sujuvuus liitettiin useaan muuhun arviointikriteeriin, erityisesti ilmaisun tarkkuuteen, laajuuteen ja idiomaattisuuteen sekä rakenteiden tarkkuuteen. Näiden kriteereiden lisäksi arvioijat yhdistivät sujuvuuden myös moneen muuhun piirteeseen, kuten tuotoksen puhekielisyyteen, kielen luontevuuteen, vaivattomuuteen kuunnella ja ymmärtää, selkeään ääntämiseen, hyvään puherytmiin, spontaaniin ja idiomaattiseen kielenkäyttöön sekä kohdekielenomaiseen rakenteeseen ja sanastoon. Sujuvuuteen taas vaikuttivat heikentävästi ilmaisun ja rakenteiden epätarkkuudet, hidas puherytmi, vähäinen tuotos ja tauot puheessa.

Vaikka arviointia ohjaaviin arviointikriteereihin kuuluu yleiskriteerin lisäksi kuusi analyyttista kriteeriä, arvioijat kiinnittivät tuotoksissa huomionsa pääosin vain kolmeen analyyttiseen kriteeriin: ilmaisun tarkkuuteen, laajuuteen ja idiomaattisuuteen, rakenteiden tarkkuuteen sekä sujuvuuteen. Esimerkiksi joustavuuden ja sidosteisuuden ja koherenssin kriteereihin viittaavia huomioita oli vähän. Ilmaisun tarkkuus, laajuus ja idiomaattisuus sekä rakenteiden tarkkuus nousivat pääosaan todennäköisesti 
siksi, että nämä kriteerit ovat opettajina toimiville arvioijille helpoiten taitotasoille määriteltävissä olevia kielenpiirteitä ja että he ovat myös tottuneet tarkkailemaan juuri näiden piirteiden hallintaa oppijoiden tuotoksista. Lisäksi arvioijat osasivat analysoida ennen kaikkea näissä kielen piirteissä ilmenneitä puutteita, ja usein näiden puutteiden syyksi mainittiin lähdekielen negatiivinen siirtovaikutus. Koulutuksen ja opetustyön kautta heille on selvästi muotoutunut käsitys siitä, miten viron kieli vaikuttaa suomen kielen sanaston ja rakenteiden hallintaan. Löydökset kuitenkin antavat viitteitä myös siitä, että Ykin arvioijien käsitysten taustalla on eri kielitaidon piirteiden arvottamista.

Arviointiin liittyy usein se, että oppijoiden tuotoksista etsitään puutteita, vaikka esimerkiksi Eurooppalaisen viitekehyksen lähtökohtana on, mitä oppija osaa ja mitä hän hallitsee. Virhelähtöisyyttä pidetään tavallisesti hieman vanhakantaisena näkökulmana kielitaidon arvioinnissa ja itse virhe-sanan käyttöä vältellään, mutta käytännössä usein juuri kohdekielestä poikkeavat piirteet huomataan helpoiten. Arvioijienkin huomioissa pääosassa olivat puutteet, mutta he nostivat oppijoiden suorituksista esiin myös piirteitä, joissa nämä onnistuivat hyvin: "sujuvuudessa on puutteita, rakenteissa myös puutteita, mutta ne ei todellakaan haittaa ymmärrettävyyttä".

Ymmärrettävyys vaikuttaa olevan varsin yleinen peruste arvioille, koska kielen puutteita usein tarkasteltiin juuri suhteessa ymmärrettävyyteen. Se ei kuitenkaan ole oma kriteerinsä Ykin arviointiperusteissa. Arvioijat ovat oman työkokemuksensa ja koulutuksen sekä Ykissä saadun arviointikokemuksen kautta tottuneet havainnoimaan ei-kohdekielisiä piirteitä siitä näkökulmasta, mikä merkitys niillä on tuotoksen ymmärrettävyyteen.

Arvioijat ilmaisivat myös usein käsityksiään siitä, kuinka helppoa vironkielisyys oli tunnistaa oppijoiden tuotoksista: "Aksentti on helppo tunnistaa virolaiseksi." Tunnistamisen helppouden vuoksi lähdekielen vaikutus annettuihin taitotasoarvioihin tulee esiin ennen kaikkea ääntämisen ja fonologian hallinnassa. Ei-kohdekieliset piirteet, kuten vironkielinen intonaatio, puherytmi tai aksentti, yhdistyivät käsityksissä mielikuvaan heikosta ääntämisen ja fonologian hallinnasta. Lisäksi arvioinnin subjektiiviset piirteet vaikuttivat ääntämisestä ja fonologian hallinnasta annettuihin taitotasoarvioihin, sillä oppijan tapa puhua ja ääntää suomea sekä suullisen tuotoksen sisältö herättivät arvioijissa tunteita ja jopa stereotypioita.

Ääntämisen ja fonologian hallinnan merkitys ja sisältö selvästi myös muuttuvat taitotasojen mukaan. Ymmärrettävyyden merkitys väheni kielitaitotason noustessa, ja vaatimukset kohdekielen kaltaiseen ääntämiseen lisääntyivät. Tätä havaintoa tukevat aiemmat tutkimukset (esim. Iwashita, Brown, McNamara \& O'Hagan 2008: 44; Sato 2011: 235-236), joiden mukaan ylemmillä taitotasoilla ääntäminen ei enää vaikuta puheen ymmärrettävyyteen, mutta oppijan odotetaan hallitsevan jo varsin luontevan ja kohdekielenomaisen ääntämyksen. Vaatimukset kohdekielenomaisesta ääntämyksestä asettavat kielenoppimiselle haasteita, koska hyvinkin suomea hallitsevalle oppijalle saattaa olla vaikea päästä eroon vieraskielisestä aksentista.

Arvioijien käsityksissä kuvastuu sosiokulttuurinen näkökulma oppimiseen ja käsitysten muotoutumiseen. Ensinnäkin arvioijien koulutustausta, työkokemus ja kokemukset erilaisista S2-oppijoista vaikuttavat heidän käsityksiinsä suomen kielen leksikaalisiin, morfologisiin, syntaktisiin ja fonologisiin piirteisiin liittyvistä vaikeuksista 
ja helppouksista sekä oppimisjärjestyksestä. Lisäksi he kantavat mukanaan käsityksiä, jotka puolestaan kumpuavat ympäröivästä yhteiskunnasta ja kulttuuritaustasta. Tällaisia ovat esimerkiksi suomen oppimisen helppous lähisukukielisyyden vuoksi, vironkielisten oppijoiden kielitaidon tasoon liittyvät odotukset sekä työ- ja arkielämässä käytetyn kielenkäytön merkitys kielenoppimiselle. Arvioijien kielitaitokäsityksiin liittyy myös affektiivisia piirteitä, jotka ovat yhteydessä ennen kaikkea oppijoiden ääntämiseen ja tapaan puhua sekä oppijan tuotoksen sisältöön.

Käsitysten tilanteisuus, monitahoisuus ja ristiriitaisuus tulevat esiin arvioijien arviointikäyttäytymisessä. Arvioijien kirjalliset huomiot oppijoiden tuotoksista eivät aina vastanneet heidän antamiaan numeerisia arvioita kielitaidosta. Kirjalliset viittaukset sujuvaan, luontevaan ja kohdekielenomaiseen tuotokseen viittasivat parempaan kielitaitoon kuin mitä heidän antamansa taitotasoarviot olivat, ja vaikka arvioijat sanallistivat suorituksia varsin samankaltaisesti, heidän käsityksensä kielitaidon tasoista kuitenkin vaihtelivat. Ristiriitaisuudet kertovat siitä, että yksittäisen arvioijan arviointikäyttäytymisen taustalla on henkilökohtaisia, toisten arvioijien käsityksistä poikkeavia käsityksiä kielitaidon keskeisistä piirteitä ja erilaisia tulkintoja arviointia ohjaavista kriteereistä. Myös suullista tuotosta arvioitaessa kielitaitoon vaikuttaa yhdistyvän kielitaidon ulkoisia tekijöitä (esim. oppijan persoonaan liittyviä piirteitä), joilla on arviointitilanteessa merkitystä.

Arvioijien arviointikäyttäytymiseen ja yleensä arviointiin vaikuttavat monet tekijät, mutta tulkittaessa havaintoja on hyvä huomioida myös tähän tutkimukseen liittyvät heikkoudet ja puutteet. Tutkimusasetelmassa käytetty puhumistehtävä oli arvioijille tuttu, keskitason tutkinnossa (taitotasot 3-4) käytetty tehtävä. Tämä saattoi ohjata osaa arvioijista taitotasojen asettelussa, vaikkakin heitä ohjeistettiin käyttämään koko arviointiskaalaa (1-6), koska oppijan kielitaito voi analyyttisten kriteereiden osalta olla testitasosta huolimatta parempi tai huonompi. Osa arvioijista piti myös tehtävän aihepiiriä liian konkreettisena, minkä vuoksi tuotosten sisältö ei heistä voinut saavuttaa ylempien taitotasojen edellyttämää abstraktiotasoa. Tuottamistehtävissä oppija voi kuitenkin itse vaikuttaa abstraktiotasoon, koska kertomistehtävien otsikko ja ohjatut kysymykset mahdollistavat monenlaiset tuotokset pyydetystä aiheesta. Lisäksi on mahdollista, että ensikielen tunnistaminen kohdisti arvioijien huomion tavallista enemmän tuotosten vieraskielisiin piirteisiin, joskin myös normaalissa arviointitilanteessa arvioijat kiinnittävät huomiota oppijan ensikieleen ja sen aiheuttamiin puutteisiin kielitaidossa (ks. Munro \& Derwing 1995; Carey ym. 2010).

Artikkeli tuo esiin useita asioita, joita voidaan hyödyntää arvioijien ohjeistuksessa. Vaikka koulutuksissa korostetaan arviointikriteereiden merkitystä, tulee koulutusten sisältöjen ohjata arvioijia entistä vahvemmin käyttämään kriteereitä arviointipäätöstä tehdessään. Lisäksi tarvitaan keskustelua siitä, mitä eri kielenpiirteillä tarkoitetaan ja miten arviointikriteereissä mainitut käsitteet tulkitaan, jotta voidaan tukea arvioijien yhdenmukaista kriteereiden käyttöä. Arvioijien saama palaute arviointilinjasta ja sen johdonmukaisuudesta auttaa heitä työssään, mutta arvioinnin luotettavuuden varmistamiseksi he tarvitsevat myös lisää tietoa omasta arviointikäyttäytymisestään. Vain siten voidaan minimoida esimerkiksi ensikielen tunnistamisen vaikutus annettaviin taitotasoarvioihin. Kun arvioija tulee tietoiseksi omien arviointiensa taustalla vaikutta- 
vista tekijöistä ja käsityksistä, hän voi tarkkailla omaa arviointikäyttäytymistään ja sitä kautta myös vaikuttaa siihen.

\section{Lähteet}

Ahola, SARI 2016: Puhetta arvioinnista. Yleisten kielitutkintojen arvioijien käsityksiä arvioinnista. - Ari Huhta \& Raili Hildén (toim.), Kielitaidon arviointitutkimus 2ooo-luvun Suomessa s. 89-109. AFinLA-e. Soveltavan kielitieteen tutkimuksia 9. Jyväskylä: Suomen soveltavan kielitieteen yhdistys.

Ahola, Sari - Tossavainen, Henna 2016: Helppoa vai vaikeaa arvioida? Yleisten kielitutkintojen suomen kielen arvioijien käsityksiä vironkielisten arvioinnista. - Lähivõrdlusi. Lähivertailuja 26 s. 27-53. https://doi.org/10.5128/LV26.01.

Ang-Av, Hui Teng - Goh, Christine Chuen Meng 2011: Understanding discrepancies in rater judgement on national-level oral examination tasks. - RELC Journal $42 \mathrm{s.}$ 31-51. https://doi.org/10.1177/0033688210390226.

Attali, Yigal 2016: A comparison of newly-trained and experienced raters on a standardized writing assessment. - Language Testing 33 s. 99-115. https://doi. org/10.1177/0265532215582283.

BACHMAn, LyLe F. 1990: Fundamental considerations in language testing. Oxford: Oxford University Press.

Barcelos, Ana Maria Ferreira 2003: Researching beliefs about SLA. A critical view. - Paula Kalaja \& Ana Maria Ferreira Barcelos (toim.), Beliefs about SLA. New research approaches s. 7-34. Dordrecht: Kluwer Academic Press.

Barcelos, Ana Maria Ferreira - Kalaja, Paula 2011: Introduction to beliefs about SLA revisited. - System 39 s. 281-289. https://doi.org/10.1016/j.system.2011.07.001.

BARKAOUi, KHALED 2010: Variability in ESL essay rating process. The role of the rating scale and rater experience. - Language Assessment Quarterly 7 s. 54-74. https://doi. org/10.1080/15434300903464418.

Best, Catherine. T. - McRoberts, Gerard W. - Goodwell, Elizabeth 20o1: Discrimination of non-native consonant contrasts varying in perceptual assimilation to the listener's native phonological system. - Journal of the Acoustical Society of America 109 s. 775-794.

Brennan, Robert L. - Brennan, Dale J. 1981: Measurements of accent and attitude towards Mexican-American speech. - Journal of Psycholinguistic Research 10 s. 487-501. https://doi.org/10.1007/BFo1076735.

Brown, H. Douglas 2004: Language assessment. Principles and classroom practices. White Plains, New York: Pearson Education.

Brown, Annie - Iwashita, Noriko - McNamara, Tim 2005: An examination of rater orientations and test-taker performance on English-for-academic-purposes speaking tasks. TOEFL, Monograph Series, MS-9. Princeton, New Jersey: Educational Testing Service.

BøHN, Henrik 2015: Assessing spoken EFL without a common rating scale. Norwegian EFL teachers' conceptions of construct. - SAGE Open October-December 2015 s. 1-12. https:// doi.org/10.1177/2158244015621956.

Carey, Michael D. - Mannell, Robert H. - Dunn, Peter K. 2010: Does a rater's familiarity with a candidate's pronunciation affect the rating in oral proficiency interviews? - Language Testing 28 s. 201- 219. https://doi.org/10.1177\%2Fo265532210393704. 
Chambers, Francine 1997: What do we mean by fluency? - System 25 s. 535-544. https:// doi.org/10.1016/So346-251X(97)0oo46-8.

Cizek, Gregory J. - Bunch, Michael B. 2007: Standard setting. A guide to establishing and evaluating performance standards for tests. London: Sage Publications Ltd. https:// dx.doi.org/10.4135/9781412985918.

Clandinin, D. Jean - Connelly, F. Michael 1986: Rhythms in teaching. The narrative of teachers' personal practical knowledge of classrooms. - Teaching and Teacher Education 2 s. 377-387. https://doi.org/10.1016/0742-051X(86)90030-2.

ConNor-Linton, JeFF 1995: Looking behind the curtain. What do L2 composition ratings really mean? - TESOL Quarterly 29 s. 762-765. https://doi.org/10.2307/3588174.

DAVIS, LARRY 2016: The influence of training and experience on rater performance in scoring spoken language. - Language Testing 33 s. 117-135.

De Costa, Peter I. 2011: Using language ideology and positioning to broaden the SLA learner beliefs landscape. The case of an ESL learner from China. - System 39 s. 347- 358. https://doi.org/10.1016/j.system.2011.07.007.

Dufva, Hannele - Alanen, Riıkka - Aro, Mari 2003: Kieli objektina - miten lapset mieltävät kielen? - Merja Koskela \& Niina Pilke (toim.), Kieli ja asiantuntijuus s. 295-316. Suomen soveltavan kielitieteen yhdistyksen AFinLA julkaisuja 61. Jyväskylä: Jyväskylän yliopistopaino.

Eскеs, Тномаs 2008: Rater types in writing performance assessments. A classification approach to rater variability. - Language Testing 25 s. 155-185.

Eskola, JARI - SuORAnta, Juha 1998: Johdatus laadulliseen tutkimukseen. Tampere: Vastapaino.

Eurooppalainen viitekehys $2003=$ Eurooppalainen viitekehys. Kielten oppimisen, opettamisen ja arvioinnin yhteinen eurooppalainen viitekehys. Helsinki: WSOY.

Gass, Susan, M. - Selinker, Larry 2001: Second language acquistion. An introductory course. London: Lawrence Erlbaum Associates.

Golombeк, Paula R. 1998: A study of language teachers' personal practical knowledge. Tesol Quarterly 32 s. 447-464.

Hammerschmidt, Sandra L. - Sudsawad, Pimjai 2004: Teacher's survey on problems with handwriting. Referral, evaluation, and outcomes. - American Journal of Occupational Therapy 58 s. 185-192. https://doi.org/10.5014/ajot.58.2.185.

Hildén, RAILI 2000: Att tala bra, bättre och bäst. Suomenkielisten abiturienttien ruotsin kielen suullinen taito testisuoritusten valossa. Helsingin yliopiston opettajankoulutuslaitos, Tutkimuksia 217. Helsinki: Helsingin yliopisto.

Honko, MARI 2017: Kieli- ja kielitaitokäsitykset tutkivan opettajan kenttäpäiväkirjamerkinnöissä. - Puhe ja kieli 37 s. 215-238. https://doi.org/10.23997/pk.63203.

Hunta, Ari 1993: Suullisen kielitaidon arviointi. - Sauli Takala (toim.), Suullinen kielitaito ja sen arviointi s. 143-225. Kasvatustieteiden tutkimuslaitoksen julkaisusarja B. Teoriaa ja käytäntöä 77. Jyväskylä: Jyväskylän yliopisto.

Huhta, Ari - Suontausta, Tuomo 1993: Suullisen kielitaidon testausmenetelmiä. - Sauli Takala (toim.), Suullinen kielitaito ja sen arviointi s. 227-266. Kasvatustieteiden tutkimuslaitoksen julkaisusarja B. Teoriaa ja käytäntöä 77. Jyväskylä: Jyväskylän yliopisto.

ILOLA, MAARIT 2018: Oppilaiden käsityksiä englannin suullisesta kielitaidosta, sen oppimisesta ja arvioinnista. Faculty of Humanities and Social Sciences. Jyväskylä: Jyväskylän yliopisto. http://urn.fi/URN:ISBN:978-951-39-7548-7.

Isaacs, Talia - Trofimovich, Pavel 2012: Deconstructing comprehensibility. Identifying 
the linguistic influences on listeners' L2 comprehensibility ratings. - Studies in Second Language Acquisition 34 s. 475-505. https://doi.org/10.1017/So27226311200o150.

Iwashita, Noriko - Brown, Annie - McNamara, Tim - O’Hagan, Sally 2008: Assessed levels of second language speaking proficiency. How distinct? - Applied Linguistics 29 s. 24-49. https://doi.org/10.1093/applin/ammo17.

Ja AKKOLA, HANNA 1997: Kielitieto kielitaitoon pyrittäessä. Vieraiden kielten opettajien käsityksiä kieliopin oppimisesta ja opettamisesta. Jyväskylä Studies in Education, Psychology and Social Research 128. Jyväskylä: Jyväskylän yliopisto.

Johnson, JefF S. - Lim, GAD S. 2009: The influence of rater language background on writing performance assessment. - Language Testing 26 s. 485-505. https://doi. org/10.1177\%2Fo265532209340186.

JÄÄSKelÄINEN, INKeRI 2002: Kun Suomi ja Viro kohtaavat. Äännevariaatioita virolaismuuttajien puhesuomessa ja muuttujien kulttuurinen sopeutuminen. Lisensiaattityö. Helsingin yliopiston suomalais-ugrilainen laitos.

KaivaPAlu, ANNEKATRIN 2005: Lähdekieli kielenoppimisen apuna. Jyväskylän yliopiston Humanistinen tiedekunta. Jyväskylä: Jyväskylän yliopisto.

2009: Vironkielisen suomenoppijan äidinkieli - ongelma, haaste vai voimavara. - Virittäjä 113 s. $382-401$.

KANG, OKIM 2008: Ratings of L2 oral performance in English. Relative impact of rater characteristics and acoustic measures of accentedness. - Spaan Fellow Working Papers in Second or Foreign Language Assessment 6 s. 181-205. https://doi.org/10.1080/15434303.2011.642631.

KIM, HyUn JUNG 2015: A qualitative analysis of rater behavior on an L2 speaking assessment. - Language Assessment Quarterly 12 s. 239-261. doi:10.1080/15434303.2015.1049353.

Lantolf, James P. - Appell, Gabriela 1994: Vygotskian approaches to second language research. New Jersey: Ablex Publishing.

LIM, GAD S. 2011: The development and maintenance of rating quality in performance writing assessment. A longitudinal study of new and experienced raters. - Language Testing $28 \mathrm{~s}$. 543-56o. doi: 10.1177/0265532211406422.

Linarce, John M. 2009: A user's guide to FACETS v3.66.o. Chigaco: Winsteps.

Lindemann, STEPHANiE 2005: Who speaks 'broken English'? US undergraduates' perceptions of non-native English. - International Journal of Applied Linguistics 15 s. 187-212. https://doi.org/10.1111/j.1473-4192.2005.00087.x.

Lumley, Tom 2002: Assessment criteria in a large-scale writing test. What do they really mean to the raters? - Language Testing 19 s. 246-276. https://doi.org/10.1191/0265532202lt230oa.

2005: Assessing second language writing. The rater's perspective. Frankfurt am Main: Peter Lang.

Mercer, Sarah 2011: Language learner self-concept. Complexity, continuity and change. - System 39 s. 335-346. https://doi.org/10.1016/j.system.2011.07.006.

Munro, Murray J. - Derwing, Tracey M. 1995: Foreign accent, comprehensibility, and intelligibility in the speech of second language learners. - Language Learning 45 s. 73-97. https://doi.org/10.1111/j.1467-1770.1995.tboo963.x.

Myford, Carol M. - Wolfe, Edward W. 2003: Detecting and measuring rater effects using Many-Facet Rasch Measurement. Part 1. - Journal of Applied Measurement $4 \mathrm{~s}$. 386-422.

2004: Detecting and measuring rater effects using Many-Facet Rasch Measurement. Part 2. - Journal of Applied Measurement 5 s. 189-227.

Neguerela-Azarola, Eduardo 2011: Beliefs as conceptualizing activity. A dialecti- 
cal approach for the second language classroom. - System 39 s. 359-369. https://doi. org/10.1016/j.system.2011.07.008.

NeittaAnmäKi, Reeta - Hirvelë, Tuija 2014: Yleisten kielitutkintojen osallistujat taustatietojen valossa. - Tarja Leblay, Tiina Lammervo \& Mirja Tarnanen (toim.), Yleiset kielitutkinnot 20 vuotta s. 46-6o. Opetushallitus: Raportit ja selvitykset 2014:16. Helsinki: Opetushallitus.

Nesdale, Drew - Rooney, Rosanna 1996: Evaluations and stereotyping of accented speakers by preadolescent children. - Journal of Language \& Social Psychology 15 s. 133-155. https://doi.org/10.1177/0261927X960152002.

Nikula, TARJA 2010: Kielikäsityksen ja kielenopetuksen kytköksiä. - Kieli, koulutus ja yhteiskunta 1(1). http://www.kieliverkosto.fi/journal (2.10.2018).

Nissilë, LeENA 2011: Viron kielen vaikutus suomen kielen verbien ja niiden rektioiden oppimiseen. Oulun yliopiston humanistinen tiedekunta, suomen kieli. Oulu: Oulun yliopisto.

OrR, Michael 2002: The FCE Speaking test. Using rater reports to help interpret test scores. - System 30 s. 143-154. https://doi.org/10.1016/So346-251X(02)0ooo2-7.

PAJARES, M. Frank 1992: Teachers' beliefs and educational research. Cleaning up a messy construct. - Review of Educational Research 62 s. 307-332. https://doi. org/10.3102/00346543062003307.

Peng, JiAn-E 2011: Changes in language learning beliefs during a transition to tertiary study. The mediation of classroom affordances. - System 39 s. 314-324. https://doi.org/10.1016/j. system.2011.07.004.

Pietikäinen, Sari - Mäntynen, Anne 2009: Kurssi kohti diskurssia. Tampere: Vastapaino.

Pollitt, Alastair - Murray, Neil. L. 1996: What raters really pay attention to. Michael Milanovic \& Nick Saville (toim.), Performance testing, cognition and assessment. Selected papers from the $15^{\text {th }}$ language research testing colloquium s. 74-91. Cambridge UK: Cambridge University Press.

Rubin, Donald L. 1992: Non-language factors affecting undergraduates' judgments of nonnative English-speaking teaching assistants. -Research in Higher Education 33 s. 511-531. https://www.jstor.org/stable/40196047 (2.1.2019).

Sakui, Keiko - Gaies, Stefen J. 2003: A case study. Beliefs and metaphors of a Japanese teacher of English. - Paula Kalaja \& Ana Maria Ferreira Barchelos (toim.), Beliefs about SLA. New Research Approaches s. 153-170. Dordrecht: Kluwer Academic Press.

SAlo, Olli-PeKKa 2006: Opetussuunnitelma muuttuu, muuttuuko oppikirja? Huomioita 7. luokan vieraiden kielten oppikirjojen kielikäsityksistä. - Päivi Pietilä, Pekka Lintunen \& Heini-Marja Järvinen (toim.), Kielenoppija tänään - Language leaners of today. AFinLAn vuosikirja 2006 s. 237-256. Jyväskylä: Jyväskylän yliopisto.

— 2010: Ruotsin opettaminen tänään ja huomenna - mitä ruotsinopettajat ajattelevat? Kieli, koulutus ja yhteiskunta 1(3). http://www.kieliverkosto.fi/journal (2.10.2018).

Sato, TAKANORI 2011: The contribution of test takers' speech content to scores on an English oral proficiency test. - Language Testing 29 s. 223-241. https://doi. org/10.1177\%2Fo265532211421162.

Sirvelt, Keaty - Mustonen, Sanna 2013: Lähdekielen vaikutus ja kielitaitotasot. Paikallissijojen kehitys oppijansuomessa. - Lähivõrdlusi. Lähivertailuja 23 s. 341-37o. https://doi. org/10.5128/LV23.14.

Siltaoja, Marjo - Vehraperä, Meri 2011: Diskurssianalyysi johtamis- ja organisaatiotutkimuksessa. - Anu Puusa \& Pauli Juuti (toim.), Menetelmäviidakon raivaajat. Perusteita laadullisen tutkimuslähestymistavan valintaan. Johtamistaidon opisto. Helsinki. 
SORAMÄKI, ANU 2014: Yleisten kielitutkintojen käytettävyys maahanmuuttoviraston näkökulmasta. - Tarja Leblay, Tiina Lammervo \& Mirja Tarnanen (toim.), Yleiset kielitutkinnot 20 vuotta s. 35-42. Opetushallitus: Raportit ja selvitykset 2014:16. Helsinki: Opetushallitus.

Sulkala, Helena 1996: Finnish as a second language for speakers of related languages. - Maisa Martin \& Pirkko Muikku-Werner (toim.), Finnish and Estonian - new target languages s. 143-157. Jyväskylä: University of Jyväskylä.

TArnanen, Mirja 2002: Arvioija valokeilassa. Suomi toisena kielenä -kirjoittamisen arviointia. Soveltavan kielentutkimuksen keskus. Jyväskylä: Jyväskylän yliopistopaino.

_ 2014: Arvioija taidon arvottajana. - Tarja Leblay, Tiina Lammervo \& Mirja Tarnanen (toim.), Yleiset kielitutkinnot 20 vuotta s. 115-124. Opetushallitus: Raportit ja selvitykset 2014:16. Helsinki: Opetushallitus.

VARIS, MARKKU 2012: Kielikäsitys yläkoulun äidinkielen oppikirjoissa. Oulun yliopiston kasvatustieteiden tiedekunta. Oulu: Oulun yliopisto. http://jultika.oulu.fi/files/ isbn9789514299728.pdf.

Vygotкsкy, Leo S. 1978: Mind in society. The development of psychological processes. Harvard, M.A: Harvard University Press.

Weigle, SARA Cushing 1994: Effects of training on raters of ESL compositions. - Language Testing 11 s. 197-223. doi: 10.1177/026553229401100206.

WeIr, Cyril J. 1990: Communicative language testing. London: Prentice Hall.

Woods, Devon 2003: The social construction of beliefs in the language classroom. - Paula Kalaja \& Ana Maria Ferreira Barchelos (toim.), Beliefs about SLA. New Research Approaches s. 201-229. Dordrecht: Kluwer Academic Press

Woods, Devon - Çakir, Hamide 2011: Two dimensions of teacher knowledge. The case of communicative language teaching. - System 39 s. 381-39o. https://doi.org/10.1016/j. system.2011.07.010.

Yki = Yleiset kielitutkinnot 2003. Puhumisen arviointikriteerit. https://www.jyu.fi/hytk/fi/laitokset/solki/yki/yleista/tietoakielitutkinnoista/arviointi (10.1.2019).

\section{Liite}

( . ) $=$ tauko

Mati:

emmä nyt (.) n-niin kovin usein käy kylässä käy. (.) koska (.) krhm (.) asuttaan kat aika pienessä kaupungissa kat ja ja ei mulla oo (.) niinku (.) monta so- prat- (.) kaveria siellä (käytymä) eikä (.) enemmän kait vaimolla niinkö. (.) ja (.) on siel pari kaverii joka (.) kene (.) kanssa kait me (.) yleensä kait niinku viikonloppuna saunottaan. (.) tai jotai semmosta (känt). (.) krhm (.) pari työkaveria vielt kenen kanssa kato otetaa muutama kalja joskus (.) silloi tällöi ket (.) ja semmosta juttuu. (.) joss (.) jos täällä tulee kait niinku vierait kait no (.) see riippuu nyt mitä tarjotaan et et (.) onks se joku (.) kahvikutsut tai illalliskutsut et see niinku (.) tarjotaankos me jotai pikkupurtavaa kait suolasta, tai (.) jotain (.) kakkua kat, (.) tai sit (.) laitetaan (.) kunno illalline kat (.) ruokinee juominee kaikkinee. (.) krhm (.) yleensä köt (.) jos mä ota- (.) meen kylään köt (.) kyl mä otan jotain, (.) jotain mukaan köt. (.) kyl se saat- saattaa olla köt ihan, (.) ihan mitä vaan köt. (.) pari piirakkaa kat tai (.) pari kakkupalaa kat tai (.) pari kaljaa kat. (.) kylässä jutellaan kat (.) ihan mistä vaan kat. 
Heiki:

öö naapuriks on meillä semmonen vanhempi pariskunta, öö emäntä on talossa .hhh kaheksankymmentneljävuottine ja isäntä on kaheksankuusvuottine.(.) me tapaamme yleensä (.) joka viikko kerran ainaki, (.) ja yleensä pihal tavata kui he ovat pihal tai mää oon sitte taas pihal tekemäs omii hommii. (.).hhh puhumme kaikennäkösist asioist et (.) mitä tarvi tehä, ja nurmikoist ja perunoist ja kaikista.(.) teemme yleensä välillä yhteistyötäki kui mää käyn heitä auttamas ruohonleikkaamises ja (.) ja kaikenlaises tommosis pihahommis. (.) naapurit on aika hyvät et ei siin mitää erikoista enää toivo että (.) ne on aika hyvät, semmone vanhempi pariskunta että. (.) ettei oo huonoi naapureita ja (.) eikä haluu semmosii huonoi naapureit kui (.) kaverit kyl välillä sanoo et heil on huonot naapurit mutta (.) mmä olen aika tyytyväine ja tykkään heist.

Maria:

minulla on tosi hyvä naapureita, (.) hyviä naapureita. minun naapurin nimeni on kaira ja hän on tosi ystävällinen (.) ja hän on tosi hyvää leipoja. (.) me tapaamme usein öö saunassa tai pihalla,(.) ehkä (.) pari tai kolme kertaa viikossa.(.) mee (.) meillä on öö (.) talon lenkkisauna, ja me tapaamme useinn (.) siellä. (.) me puhumme paljon lapsista, koska meillä molemmilla on (.) lapset. (.) jooo (.) myös meitän lapset tykkäävät leikkiä (.) yhtensä (.) yht- (.) yhtensä. (.) me puhumme paljon lapsista, mitennn, (.) omillainen on hyvää ruokaa, (.) mite- mistä lapset tykkäävät, (.) öö käymme (.) myös uimahallissa, leikkipuistoissa, (.) öö, leipomme (.) leivomme kakkuja, (.) jaa myösm- myöss pyöräilemme metsässä. (.) öö kesäin mee menemme joskus grillamaan (.) meren (.) rannalle, (.) jaa (.) mee (.) ollaan paljon yhtessä. hhh (.) mä toivon, (.) ettää (.) että me molemmat asui-asuisimme siellä vielä kauan, koska (.) kun minä laitan ruokaa ja hän laittaa ruokaa, me vaihtamme ja maistamme (.) meidän ruoki

Julia:

mies ja naine avopari (.) tavatan käytävällä,(.) hississä (.) hhh sillon tällön. (.) keskustelemme säästä (.) ja muita kuulumisia. (.) joskus (.) keskustelemme parvekkeella kukkasten kastelemisesta (.) ja muuta (.) kivaa. (.) emmä koskaan mitää pyytä niilt mutta (.) mutta jos ne tarvitsevat apua mä aina (.) olen ystävällinen niille. (.) hyvä naapuri on aina hiljanen ja (.) mäkin toivon olla (.) niille hyvä. (.) huono naapuri minulla ei ole mä en tiedä sellaisii. (.) ehkä huono naapuri olis sillanen(.) mitää tota no en tiedä sillasta. 


\section{Fluent but influenced by Estonian: Rater perceptions of the spoken Finnish skills of L1 Estonian speakers in National Certificate exams}

This paper studies the perception of National Certificate $(\mathrm{NC})$ raters $(\mathrm{N}=44)$ of the spoken Finnish of L1 Estonian speakers. The paper further describes ways to identify the learners' L1 and what effect this identification has on the perception of their language skills. The approach relies on contextualised conceptual research.

The data is gathered from the research project 'Broken Finnish: Accent Perceptions in Societal Gatekeeping', funded by the Academy of Finland. Concentrating on five different L1 languages, the project examines the influence of foreign accent on assessing spoken Finnish. This article focuses on the spoken products of L1 Estonian speakers $(\mathrm{N}=10)$ who were assessed using the NC assessment criteria by granting each learner separate proficiency levels on the basis of both a general holistic criterion and six analytical criteria. In addition, the raters were asked to write up their comments regarding the learner's product, to name their L1, and to give reasons for these assumptions. These comments have been analysed from the perspective of discourse analysis.

Educational background, work experience, and experience of different L2 learners as well as surrounding societal and cultural factors are all reflected in the raters' perceptions. L1 Estonian was readily identified and this identification had clear implications for the perceptions of the learner's skills. The impact of the learner's source language was often commented upon, and there were certain expectations regarding their proficiency level due to the proximity of the two languages. The products were described as fluent, natural and understandable, but these concepts were related to different analytical criteria and their significance varied from rater to rater. Assessments focused on accuracy and range as well as grammatical control, and better assessments were granted to those identified as Estonians than those who were not. As the Estonians were identified from their pronunciation, the raters found several shortcomings with respect to pronunciation control and phonology. In addition to pronunciation, the learner's manner of speaking and speech content were extrapolated to form wider assumptions regarding their skill levels. 


\section{Sujuvaa, mutta viron kielen vaikutusta: Yleisten kielitutkintojen arvioijien käsityksiä vironkielisten suomenoppijoiden suullisesta taidosta}

Artikkelissa tarkastellaan Yleisten kielitutkintojen (Yki) arvioijien ( $\mathrm{N}=44)$ käsityksiä vironkielisten suomenoppijoiden suullisesta kielitaidosta. Lisäksi artikkelissa kuvataan, mistä oppijoiden ensikieli tunnistetaan ja kuinka tunnistaminen vaikuttaa käsityksiin kielitaidosta. Näkökulma kielitaitokäsityksiin perustuu kontekstuaaliseen käsitystutkimukseen.

Artikkeli on osa Suomen Akatemian Rikkinäistä suomea - Aksenttien arviointi yhteiskunnallisena portinvartijana -tutkimushanketta, jossa tarkastellaan viiden ensikielen kautta vieraan aksentin vaikutusta suomen kielen taidosta annettaviin arvioihin. Tässä artikkelissa keskitytään vironkielisiin oppijoihin $(\mathrm{N}=10)$, joiden puhesuorituksille arvioijat antoivat Ykin arviointikriteereiden avulla erilliset taitotasoarviot sekä holistisesta yleiskriteeristä että kuudesta analyyttisestä kriteeristä. Lisäksi arvioijia pyydettiin kirjoittamaan huomioita suorituksesta, nimeämään oppijoiden ensikieli ja perustelemaan oletuksensa. Artikkelissa keskitytään arvioijien kirjallisiin huomioihin, joita analysoidaan diskurssianalyysin avulla.

Analyysi osoittaa, että koulutustausta, työkokemus ja kokemukset erilaisista S2oppijoista sekä ympäröivä yhteiskunta ja kulttuuri kuvastuvat arvioijien kielitaitokäsityksissä. Viro ensikielenä tunnistettiin hyvin, ja tunnistamisella oli yhteyksiä käsityksiin oppijan taidosta. Lähdekielen vaikutusta kommentoitiin usein, ja kielitaidon tasoon näytti liittyvän odotuksia lähisukukielisyyden vuoksi. Suorituksia kuvailtiin sujuviksi, luonteviksi ja ymmärrettäviksi, mutta ne yhdistettiin eri analyyttisiin kriteereihin, ja niiden merkitys vaihteli arvioijien kesken. Arvioinnissa keskityttiin ilmaisun tarkkuuteen ja laajuuteen sekä rakenteiden hallintaan, joista vironkieliseksi tunnistetut saivat ei-tunnistettuja oppijoita paremmat arviot. Sen sijaan ääntämisen ja fonologian hallinnassa vironkieliseksi tunnistetuilla nähtiin paljon puutteita, koska lähdekieli tunnistettiin juuri ääntämisestä. Ääntämisen lisäksi puhetavalla ja tuotoksen sisällöllä oli yhteyksiä käsityksiin oppijan taidosta.

Kirjoittajan yhteystiedot:

etunimi.sukunimi@jyu.fi

Kirjoittaja toimii tutkimuskoordinaattorina Jyväskylän yliopistossa. 